\title{
MEDIAÇÃO DE CONFLITOS SOCIOAMBIENTAIS: UMA ALTERNATIVA À EFETIVAÇÃO DO DIREITO FUNDAMENTAL AO MEIO AMBIENTE ECOLOGICAMENTE EQUILIBRADO
}

\author{
NatÁlia Luiza Alves Martins \\ Jueza federal laboral \\ Tribunal Regional do trabalho da $8^{a}$ região (Brasil) \\ Máster en Derecho Constitucional y especialización en Derecho Ambiental \\ Universidade de Fortaleza \\ natalialuizaa@hotmail.com \\ VALTER MOURA Do CARMO \\ Doctorando en Derecho por Universidade Federal de Santa Catarina (UFSC) \\ Estancia de investigación en Universidad de Zaragoza \\ Becario de PDSE/CAPES (Brasil) \\ valter.moura@posgrad.ufsc.br
}

Recebido: 23 de maio de 2015 / Aceito: 22 de junho de 2015

RESUMO: Os problemas ecológicos e o acesso à justiça são temas de constantes discussões no âmbito jurídico. O descrédito no Poder Judiciário brasileiro pode ser considerado um dos responsáveis pelo aumento da procura dos chamados meios alternativos de soluções de conflitos, como a arbitragem, a negociação, a conciliação e a mediação. Em geral, os conflitos resolvidos por meio de soluções alternativas são de caráter privado, nos quais o poder estatal não possui ingerência. No que pese o fato de o direito ambiental ser pautado por normas públicas, de observância obrigatória, muitos conflitos envolvendo esta temática podem ser resolvidos efetivamente com o uso da mediação. Neste contexto, por meio de pesquisa bibliográfica, buscar-se-á analisar a 
aplicação de meios alternativos de solução de conflitos, em especial a mediação, como forma de resolução dos conflitos ambientais. A escolha desse método de resolução se deu posto que os fatores positivos de sua aplicação superam os fatores supostamente considerados negativos.

ABSTRACT: Ecological problems and access to justice are topics of constant discussion in the legal field. The discrediting in the Brazilian judiciary can be considered one of the responsible for the increased demand of so-called alternative means of conflict resolution, such as arbitration, negotiation, conciliation and mediation. In general, conflicts solved by alternative means of solution are private disputes where state power has no interference. Despite the fact that environmental law be guided by public rules with mandatory observance, many conflicts involving the topic can be effectively solved through the use of mediation. Within this context, from the literature it is hoped examine the application of alternative dispute resolution, particularly mediation as a means of environmental conflicts resolution. The choice of this method of resolution was because of the positive factors of its implementation outweigh the factors considered supposedly negative.

RESUMEN: Los problemas ecológicos y el acceso a la justicia son temas de constantes discusiones en el ámbito jurídico. El descredito en el Poder Judicial brasileño puede ser considerado uno de los responsables del aumento de la busca de los llamados medios alternativos de solución de conflictos, como el arbitraje, la negociación, la conciliación y la mediación. En general, los conflictos resueltos por medio de soluciones alternativas son de carácter privado, en los que el poder del Estado no tiene injerencia. A pesar del hecho de que el Derecho ambiental se orienta por normas públicas, de observancia obligatoria, muchos de los conflictos que involucran esta temática se pueden resolver de manera efectiva con el uso de la mediación. En este contexto, por medio de la investigación bibliográfica, se buscará hacer un análisis de la aplicación de medios alternativos de resolución de conflictos, en particular la mediación como forma de resolver los conflictos ambientales. La elección de este método de solución viene justificada en que los factores positivos de su aplicación superan los factores supuestamente considerados negativos. 
RESUM: Els problemes ecològics i l'accés a la justícia són temes de discussions constants en l'àmbit jurídic. El descrèdit del Poder Judicial brasiler pot ser considerat com un dels responsables de l'augment en la cerca dels anomenats mitjans alternatius de solució de conflictes, com l'arbitratge, la negociació, la conciliació i la mediació. En general, els conflictes resolts mitjançant solucions alternatives són de caràcter privat, en els que el poder de l'Estat no té ingerència. Malgrat que el dret ambiental s'orienta per normes públiques, d'observança obligatòria, molts dels conflictes que involucren aquesta temàtica es poden resoldre de manera efectiva a través de la mediació. En aquest context, mitjançant la recerca bibliogràfica, es busca fer una anàlisi de l'aplicació dels mitjans alternatius de resolució de conflictes, en particular, la mediació, com a forma de resoldre els conflictes ambientals. L'elecció d'aquest mecanisme de solució ve donada pel fet que els factors positius de la seva aplicació superen els factors suposadament considerats negatius.

PALAVRAS-CHAVE: Conflitos Ambientais - Direito Ambiental - Meios Alternativos de Solução de Conflitos - Mediação.

KEYWORDS: Environmental Conflicts - Environmental Law - Alternative Means of Conflict Resolution - Mediation.

PALABRAS CLAVE: Conflictos ambientales — Derecho ambiental — Medios alternativos de resolución de conflictos — mediación.

PARAULES CLAU: Conflictes ambientals — Dret ambiental — Mitjans alternatius de resolución de conflictes — Mediació.

SUMÁRIO: I. Introdução. II. Meios Alternativos de solução de conflitos. 1. Arbitragem. 2. Negociação. 3. Conciliação. 4. Mediação. 4.1. Objetivos. 4.2. Princípios. III. Conflitos socioambientais. IV. A mediação de conflitos socioambientais. 1. Fatores negativos à mediação ambiental. 1.1. Grande quantidade de atores sociais. 1.2. Limites formais — impossibilidade de interferência nas disposições legais. 1.3. Complexidade dos temas envolvidos. 1.4. Ausência de relação continuada entre os envolvidos e diferença de poder entre as partes. 2. Fatores positivos à mediação ambiental. 2.1. Celeridade no processo de negociação. 2.2. Decisões mais econômicas. 2.3. Legitimação da decisão e consequente 
cumprimento do acordo. 2.4. Decisões pró meio-ambiente. 2.5. Efetivação de princípios ambientais. V. Considerações finais. VI. Referências.

\section{INTRODUÇÃO}

O direito ambiental, como ramo autônomo da ciência jurídica, vem ganhando maior importância não só nos cenários jurídicos como em toda a sociedade. Diversos são os autores que inclusive abordam esse direito sob uma perspectiva dos Direitos Humanos já que "negar a possibilidade de aplicação do domínio dos direitos humanos ao meio ambiente equivaleria a tolher o exercício de uma das mais elevadas funções a que se presta o Direito: a proteção da pessoa humana $[\ldots]^{1 \text { ”. }}$. Essa crescente relevância é resultado de uma série de acontecimentos naturais que despertaram a sociedade para a realidade ambiental a qual vivemos.

A Constituição Federal do Brasil de 1988 ficou conhecida como a "Constituição Verde", recebeu esta nomenclatura por ter sido uma das primeiras constituições no mundo a trazer em seu bojo um capítulo próprio reservado ao meio ambiente. A elevação dos direitos ambientais a status de norma constitucional denota que tais direitos vêm ganhando a devida importância perante a sociedade.

Sabemos que a preocupação com a conservação do meio ambiente não se trata apenas de mais uma questão ideológica, mas uma real necessidade. Contudo, apenas após a ocorrência de fatos danosos em prejuízo do meio ambiente e pelos quais a natureza tenta pedir ajuda, as pessoas passaram a se preocupar e mostrar interesse em reverter esse triste quadro.

A crise ambiental deu sucedâneo ao surgimento de diversas normas de cunho ambiental, entretanto, a realidade aponta para a ineficácia de tais normas. No que concerne ao ordenamento jurídico brasileiro, podemos dizer que dita ineficácia provém da inaplicabilidade e não da inexistência de tais normas. Em paralelo à ineficácia das normas de caráter ecológico verificamos um alto nível de falhas na efetivação de direitos fundamentais, além do direito ao meio ambiente ecologicamente equilibrado.

No que se refere aos aspectos processuais, envolvendo as demandas dos mais diversos setores, são constantes as queixas da não observância dos primados básicos previstos

\footnotetext{
${ }^{1}$ COSTA KOURY, A. B. y LEÃO SOUSA, D., "O Direito Ambiental sob a Perspectiva da Proteção Internacional à Pessoa Humana”. Revista do Instituto Brasileiro de Direitos Humanos, 2009. p. 20
} 
em nosso texto constitucional. $\mathrm{O}$ acesso à justiça, a razoável duração do processo, o devido processo legal, dentre outros direitos fundamentais, são constantemente violados, gerando uma verdadeira insatisfação social e descrédito no poder judiciário.

Visando afastar as consequências oriundas da chamada "crise do judiciário" foi que se passou a regulamentar os meios alternativos de solução de conflitos. Esses meios alternativos têm se mostrado como verdadeiros instrumentos de acesso à justiça, entretanto não devem ser vistos como uma forma ineficaz de resolução da lide. Observa Andrine OLIVEIRA NUNES ${ }^{2}$ que "Esta conduta de deter o Poder Judiciário como quase única opção de resolução de controvérsias finda por congestionar este veículo de acesso à justiça, descreditando a jurisdição como instituição de segurança jurídica".

Sendo o direito ao meio ambiente ecologicamente equilibrado, direito humano per si, diretamente relacionado ao direito à vida, deve ser visto como uma espécie de conflito prioritário. Os conflitos envolvendo questões relacionadas ao meio ambiente devem ser resolvidos o mais breve possível, sob pena de se ferir direitos fundamentais, bem como de tornar ineficazes as normas ambientais em razão da irreversibilidade de alguns atos envolvendo bens ecológicos. A precaução e prevenção, princípios intrínsecos desse ramo do direito, demonstram a fragilidade dos bens naturais, que devem ser preservados para as presentes e futuras gerações, não admitindo uma postura precária nas resoluções de conflitos que o envolvam.

Em geral, os conflitos socioambientais apresentam uma real necessidade de solução imediata e efetiva, e não podem ficar à mercê do Estado e de uma possível prestação ineficaz do Poder Judiciário, muitas vezes excessivamente moroso.

Por essas razões e tendo a mediação como uma forma de construção de consenso e meio eficaz de solução de conflitos, foi que buscamos analisar a proteção jurídica ambiental, verificando a sua efetividade através das decisões judiciais e a possibilidade de utilização da mediação como instrumento de auxílio na efetivação de tais direitos, trazendo vantagens na efetivação da proteção ambiental.

\footnotetext{
${ }^{2}$ OLIVEIRA NUNES, A. Poder judiciário e mediação de conflitos: a possibilidade da aplicação do sistema de múltiplas portas na prestação jurisdicional. Tese (Doutorado em Direito). Fortaleza, Brasil, Universidade de Fortaleza, 2014. p. 232
} 


\section{MEIOS ALTERNATIVOS DE SOLUÇÃO DE CONFLITOS}

A atual sociedade, complexa e em constante evolução, apresenta, a cada dia, novos conflitos das mais diversas ordens. Nesse diapasão, novas formas de solução de conflitos, os chamados meios alternativos de solução de conflitos, também conhecidos como meios consensuais de resolução de disputas, ou ainda, resolução alternativa de disputas (ADR), mostram-se como um caminho hábil para se chegar ao objetivo da justiça, e da paz social.

Dentre os meios acima referidos destacam-se a arbitragem, a negociação, a conciliação e a mediação, essa última, objeto central de estudo do presente trabalho. É, no entanto, interessante fazer uma sumária distinção entre os demais métodos para uma melhor compreensão da presente proposta, bem como para verificar a adequação do uso da mediação nos conflitos socioambientais com os fins pretendidos por esse meio pacificador de lides.

\section{Arbitragem}

Formalmente instituída pela Lei no 9.307 de 23 de setembro de 1996, a arbitragem consiste em um mecanismo de solução extrajudicial de conflitos, por meio do qual, as partes, em comum acordo, levam o problema a um terceiro imparcial, que deverá julgar a lide. Portanto, trata-se de um procedimento de heterocomposição, assim como ocorre com o poder judiciário, onde quem soluciona o caso é um terceiro estranho às partes, sendo esse terceiro quem ditará as "regras finais do jogo".

Em geral, os conflitos levados à resolução através da arbitragem são de cunho econômico que, em razão da necessária rapidez e sigilo nas soluções dos problemas, acabam por encontrar neste mecanismo um caminho cômodo para pôr fím à demanda.

Portanto, pode-se definir a arbitragem como "um meio de resolver litígios civis, atuais ou futuros, sobre direitos patrimoniais disponíveis, através de árbitro ou árbitros, escolhidos pelas partes, cujas decisões produzem efeitos jurídicos das sentenças proferidas pelos órgãos do Poder Judiciário" ${ }^{3}$.

\footnotetext{
${ }^{3}$ DE ALBUQUERQUE ROCHA, J., Lei da arbitragem: uma avaliação crítica, Atlas, São Paulo, 2008. p. 22.
} 


\title{
2. Negociação
}

Difere dos demais meios analisados por não haver (em regra) um terceiro envolvido no decorrer do procedimento, a negociação se caracteriza pela mútua cedência. As partes em conflito se auto avaliam e chegam a uma solução plausível para ambas através de diálogos por elas mesmas dirigidos. Ou seja, as partes entram em um acordo quanto à solução do problema. Segundo Gloria MORÁN:

\begin{abstract}
Por negociación (negotiation) se entiende el cauce de diálogo por el que optan las partes implicadas en un conflicto o disputa, con la finalidad de alcanzar un acuerdo en el que renuncian proporcionalmente a parte de sus demandas. El conocimiento de este campo de estudio se conoce como teoría de la negociación y es aplicada en el ámbito político, diplomático y jurídico. Dos son los tipos básicos desde los que se suele afrontar la negociación: el competitivo y el integrativo. En el primero las demandas iniciales son altas y la tensión entre las partes es creciente porque se aspira a obtener el mejor resultado unilateral. En el segundo la actitud es sustancialmente colaborativa y en ella las partes son expuestas al punto de vista del contrario desde el dialogo abierto, en el que las personas y sus diversas personalidades deben distanciarse del objeto de la disputa, y el objetivo es el interés común de las partes y no sus posiciones contrapuestas ${ }^{4}$.
\end{abstract}

Pode ser considerada a forma mais comum de solução de conflitos, sendo colocada em prática diariamente e em todas as espécies de conflito. Através do diálogo, chega-se a uma solução e somente quando esse não for possível, ou quando não resultar em um consenso é que as partes deverão buscar outros meios de solução de conflitos.

\section{Conciliação}

Ainda que haja a interferência de um terceiro para facilitar o diálogo entre as partes, essas também são as principais responsáveis pelo acordo realizado, por isso também é considerado um meio de autocomposição.

A conciliação poderá ser extrajudicial ou judicial, ou seja, como uma das etapas do processo judicial. Em geral, ambas possuem o mesmo modus operandi, um terceiro imparcial auxiliará as partes na busca por um entendimento, podendo interferir no

\footnotetext{
${ }^{4}$ MORÁN, G., "La mediación en EEUU: vías alternativas de negociación y resolución de conflictos: una nueva cultura socio-jurídica. La experiencia estadounidense", SOUTO GALVÁN, E. (dir.), La mediación: un instrumento de conciliación, Dykinson, Madrid, 2010. p. 22
} 
mérito da questão, residindo aqui a maior distinção entre este mecanismo e a mediação. Embora seja comum a equiparação entre esses dois métodos, ambos possuem peculiaridades próprias distinguindo-se,

[...] porque el mediador a lo que se dedica es a movilizar las barreras que impiden la comunicación entre las partes en conflicto, a ayudarles a disipar las percepciones erróneas que ambos mantienen respecto a la idiosincrasia e intenciones de la otra parte, y a propiciar, por tanto, un clima en el que ambas partes valoren lo que de positivo pueden obtener restaurando la relación para el cumplimiento de objetivos comunes 5 .

A diferença chave entre a conciliação e a mediação encontra-se nos objetivos precípuos e na postura do terceiro envolvido, ou seja, na técnica de realização da sessão. $\mathrm{Na}$ conciliação, o terceiro poderá intervir e sugerir soluções para o caso, visando à resolução do conflito e à realização de um acordo. Já na mediação, o mediador assume uma postura com um mínimo de "interferência", não sendo aconselhável a influência deste nas possíveis soluções. A mediação visa à construção de um consenso mútuo, onde as próprias partes, e somente elas, são legitimadas a encontrar a melhor solução.

\section{Mediação}

A mediação é um dos meios alternativos de solução de conflitos no qual as partes envolvidas são as próprias a encontrarem uma solução plausível para o mesmo.

La mediación como alternativa en la resolución de conflictos, en los que una o varias personas ayudan a otra $u$ otras a tomar sus propias decisiones, probablemente sea tan antigua como la humanidad. No es una creación actual, sino una adaptación moderna basada en culturas antiguas, sociológicamente diferentes unas de otras, en distintos periodos históricos ${ }^{6}$.

Para Jay FOLBERG e Alison TAYLOR ${ }^{7}$,

\footnotetext{
${ }^{5}$ HOYO SIERRA, I. A., "La idoneidad de los métodos alternativos de solución de conflitos", GONZALO QUIROGA, M. (dir.). BAZAGA FERNÁNDEZ, I.; GONZALO QUIROGA, M. y VENTAS SASTRE, R. (coord.), Métodos alternativos de solución de conflictos: perspectiva multidisciplinar, Universidad Rey Juan Carlos/Editorial Dykinson, Madrid, 2006. p. 359

${ }^{6}$ GONZÁLEZ-CAPITEL, C., Manual de mediación. 2. ed. Atelier, Barcelona, 2001. p. 19

${ }^{7}$ FOLBERG, J. y TAYLOR, A. Mediación: Resolución de conflictos sin litigio. Limusa, México, D.F., 1996. p. 26
} 
La práctica de la mediación comprende un campo tan extenso que no permite una definición estricta. Los detalles especificos de la mediación dependen de qué es lo que está sometiéndose a mediación, las partes en desavenencias, quién está llevando a cabo la mediación, y el medio en el cual se ofrece la mediación. La mediación es, por principio y sobre todo, un proceso que trasciende el contenido del conflicto que se pretende resolver.

Em geral, os conflitos levados ao judiciário acabam por gerar uma insatisfação em uma das partes (aquela que sucumbiu à disputa) isso porque, na maioria das vezes as disputas judiciais acabam por ser inflamadas de razão, tanto de um lado como de outro, pois as partes adversárias revestem-se de todas as armas possíveis para a defesa daquilo que acreditam ser seu direito, de forma que apenas uma delas consegue "convencer" $o$ julgador.

Já no processo de mediação, ocorre de maneira distinta, através da solução encontrada por ambas as partes, apoiados em uma posição dialética e na busca de um objetivo comum (resolver o problema), os conflitantes acabam por resolver as pendências de maneira que ambos saiam ganhando. Pode-se citar como um dos objetivos da mediação a busca por um sentimento de "ganho", todos os envolvidos devem sair ganhando, e isso somente poderá ser atingido através de um consenso entre os conflitantes. Com sua utilização poderá:

[...] llegar a establecerse nuevas reglas de juego en la cultura con la cual se estructura la sociedad. Y es que el desafio, ya ineludible, frente al cual nos enfrentamos, no es otro que el de transformar una "cultura del litigio" en una "cultura del acuerdo". En aquella cuyos rasgos característicos son la unión solidaria -la complementariedad-sostenida en la diversidad, el respeto por lo distinto, el intercambio sin confrontación, la resolución del conflicto en lugar de ocultarlo o evitarlo, la explicitación del disenso para buscar y encontrar desde alli el consenso, la existencia de diálogos -no monólogos-, y la cohesión social que sirva a una mejor calidad de vida, siendo ésta un elemento básico del que todos deben disfrutar ${ }^{8}$.

\footnotetext{
${ }^{8}$ MARCELO NATÓ, A. y RODRÍGUEZ QUEREJAZU, G., "Mediación comunitaria: practicar una ética de la paz", GONZÁLEZ-CAPITEL, C. (coord.), Mediación x 7, Atelier, Barcelona, 2001. p. 82
} 
Importante ressaltar, ainda, a existência de múltiplas concepções ou correntes relativas à mediação. Para Oscar Daniel FRANCO CONFORTI ${ }^{9}$ é possível reconhecer sete modelos de mediação: 1) mediação como solução de problemas (Havard); 2) mediação transformativa; 3) mediação circular-narrativa; 4) mediação sistémica; 5) mediação apreciativa; 6) mediação de compromisso; 7) mediação como resolução de conflitos. São na realidade posições teóricas que veem de maneira distinta a mediação.

$\mathrm{Na}$ mediação como solução de problemas, o autor ${ }^{10}$ apresenta as seguintes características desse modelo: Se identifica o problema e se separá-lo das pessoas (empatia, escuta ativa etc.); concentra-se nos interesses e não nas posições, deve-se gerar opções de mutuo benefício (chuva de ideias); avalia-se essas opções com critérios objetivos (critérios externos, judiciais, morais, de mercado, tradição etc.); avaliação conforme o MAAN (melhor alternativa a um acordo negociado), elaboração e formalização dos acordos com uma ata e/ou contrato.

A mediação transformativa ou transformadora, criação de Robert BARUCH BUSH e Joseph FOLGER, possui um viés terapêutico, marcado pelo o que eles chamam "histórias de transformação"11, colocando ênfases na comunicação e nas relações interpessoais das partes. Esse modelo vê no conflito a possibilidade de mudança no relacionamento das partes. Encontra no problema um caminho para auxiliar na melhoria dos diálogos e demais conflitos que por ventura venham a existir. O foco central da mediação será as partes envolvidas e não o problema, havendo uma mudança, uma transformação das partes, o problema será resolvido de maneira a agradar ambas.

A mediação inicialmente tinha por objetivo, neste modelo, diminuir as diferenças entre as partes, ou eliminá-las por meio do acordo. Com o aperfeiçoamento dos processos de mediação, o objetivo se ampliou, visando ao desenvolvimento do reconhecimento da alteridade, do reconhecimento do outro como sujeito pensante, atuante e sofredor. Busca-se então, alcançar o desenvolvimento de mudanças nas

\footnotetext{
${ }^{9}$ FRANCO CONFORTI, O. D. Incidencia de la Mediación de Conflictos en la Tutela Judicial Efectiva. Tesis (Doctorado en Derecho). Ciudad Real, España, Universidad de Castilla La Mancha, Instituto de Resolución de Conflictos, 2014. pp. 79-80

${ }^{10}$ FRANCO CONFORTI, O. D. Incidencia ... cit. p. 85

${ }^{11}$ BARUCH BUSH, R. y FOLGER, J., La Promesa de la Mediación: cómo afrontar el conflicto mediante la revalorización y el reconocimiento. Granica, Buenos Aires, Argentina, 1999. p. 99
} 
pessoas, ao descobrir suas próprias habilidades, potencialidades, responsabilidades e o reconhecimento do outro como parte do conflito ${ }^{12}$.

Tem como escopo a transformação da pessoa, do "eu", a mudança na forma de enxergar o problema será uma mera consequência da transformação ocorrida. Foca a solução na pessoa para que essa ressignifique valores e para que se possa chegar a uma solução. Nesse modelo a mediação será exitosa,

[...] no solo cuando se llega a un acuerdo, sino especialmente cuando además del acuerdo alcanzado, éste es consecuencia o resultado de la transformación positiva de la situación de conflicto o crisis preexistente. Ello supone que se ha debido producir un objetivo mejoramiento de la situación entre las partes, comparada con la que había antes del acuerdo ${ }^{13}$.

E como o próprio nome indica seria uma etapa de transformação das pessoas ali presentes, seria uma forma de construção de consenso mútuo. A mediação transformativa é a chamada de alternativa, ou terapia do reencontro. ${ }^{14}$

Ainda sobre essa corrente, Tânia ALMEIDA nos ensina:

Nomeada, e assim conhecida, como Mediação Transformativa, esse tipo de trabalho tem por objetivo enfrentar o conflito por meio do fortalecimento próprio e do reconhecimento dos outros. O fortalecimento próprio - empowerment - está baseado na identificação dos reais interesses e necessidades de cada um dos mediandos; ao passo que o reconhecimento do(s) outro(s) - recognition - está voltado para a identificação dos reais interesses, necessidades e valores do(s) outro(s). Para Bush e Folger, esses são os ganhos sociais mais significativos, propiciados pelo diálogo via Mediação. Para os autores, o diálogo entre ser atendido e atender, desde que possível para ambos, é transformador e se traduz em acordo como uma conseqüência natural para aqueles que genuinamente

\footnotetext{
${ }^{12}$ GRAZIOTTIN COSTA, T. N. y ZAMBAM, N. J. "A crise da jurisdição estatal: possibilidade de resolução de conflitos pela mediação e a perspectiva da moral e da autonomia da vontade na ótica Kantiana", MIRANDA, J. y AMADO GOMES, C. (coord.), QUEIROZ CAÚLA, B. y MOURA DO CARMO, V. (org.), diálogo ambiental, constitucional e internacional, Lisboa, Instituto de Ciências Jurídico-políticas, 2015. pp. 214-215

${ }^{13}$ HERNÁNDEZ RAMOS, C. "Modelos aplicables en mediación intercultural", BARATARIA: Revista Castellano-Manchega de Ciencias Sociales, núm. 17, 2014.

${ }^{14}$ ALBERTO WARAT, L., O oficio do mediador, Habitus, Florianópolis, 2001. p. 84
} 
vivenciaram empowerment e recognition. A autocomposição traduzida em acordo transforma-se em conseqüência e não em objeto na Mediação Transformativa ${ }^{15}$.

O modelo de mediação circular-narrativa, foi desenvolvido por Sara Cobb "el cual está totalmente ubicado en los nuevos paradigmas, al apoyarse en las teorías posestructurales de la narrativa. Trata de cambiar la historia que cada parte ha elaborado y conseguir acuerdos en la medida de lo posible" ${ }^{\text {. }}$. Para Oscar CONFORTI ${ }^{17}$ nessa proposta de modelo temos que assumir que a significação dos problemas e objetivos das partes encontra sua origem em suas narrativas; deve-se trabalhar sobre cada narrativa, desestabilizando-as para transforma-las; busca-se legitimar as outras narrativas; modificar as relações ou inter-relações das partes; criação de uma terceira narrativa que reúna ambos discursos e por fim se alcança um acordo que solucione o problema.

Já a mediação sistémica, segundo Oscar FRANCO CONFORTI, ${ }^{18}$ toma como ponto de partida os conceitos de "totalidade", "circularidade e retroalimentação" e "equifinalidade". Normalmente realizado no âmbito familiar, se trabalha nesse modelo a importância e complexidade dos membros do sistema, a abertura e relação que possuem com o entorno, a história e socialização, a auto-organização/autopoiese. Francisco CORSÓN PEREIRA e Eva GUTIÉRREZ HERNANZ ${ }^{19}$ destacam nesse modelo a importância

[...] que da al análisis global y particular de las familias, a las interrelaciones personales, a las relaciones entre subsistemas, la preeminencia de la visión totalizadora de la familia como sistema dentro de un proceso de cambios $y$ adaptaciones mutuas; por lo que cualquier conflicto familiar no tiene por qué desarrollar una crisis en sí misma, es decir, el conflicto afecta a las interacciones personales, mientras que la crisis se da si el conflicto afecta a la organización o estructura familiar. Esta idea o axioma es interesante pues nos muestra lo importante que es la detección de algunos conflictos que se producen entre miembros de la familia, que deben ser tratados dentro de una delimitación precisa,

\footnotetext{
${ }^{15}$ ALMEIDA, T., (2005). Mediação de conflitos: Um meio de prevenção e resolução de controvérsias em sintonia com a atualidade. Recuperado no día 33 de abril de 2015, de http://www.mediare.com.br/08artigos_13mediacaodeconflitos.html.

${ }^{16}$ MUNUERA GÓMEZ, P. "El modelo circular narrativo de Sara Cobb y sus técnicas", PORTULARIA, vol. VII, núm. 1-2, 2007.

${ }^{17}$ FRANCO CONFORTI, O. D. Incidencia ... cit. p. 112.

${ }^{18}$ FRANCO CONFORTI, O. D. Incidencia ... cit. p. 118.

${ }^{19}$ CORSÓN PEREIRA, F. y GUTIÉRREZ HERNANZ, E., Mediación y teoría, Dykinson, Madrid, 2014. p. 107
} 
considerando también al resto de la familia. Así, a veces se habla de crisis familiar cuando se trata únicamente de conflictos o problemas concretos entre algunos de sus miembros.

O quinto modelo de mediação seria a apreciativa ou diálogos apreciativos. Nessa proposta temos que: $:^{20} 1$ ) a linguagem (positiva ou negativa) é determinante em quanto à construção da realidade; 2) A linguagem e as imagens utilizadas pelo mediador e os mediados possuem o poder de criar uma nova realidade, realidade a qual podem e desejam dirigir-se, já que é algo vivido, conhecido e valorado pelos participantes de forma positiva; 3) A realidade sempre é subjetiva e todas as realidades devem ser consideradas e expostas. Será de vital importância que tanto o mediador como os mediados explorem suas percepções positivas, seja de si mesmo, como do outro participante; 4) Não se trata de negar, ocultar o ignorar as coisas negativas, e sim simplesmente de não ocupar nosso tempo e esforço para tratar de solucioná-las.

\section{Segundo Raúl CALVO SOLER ${ }^{21}$}

Para los defensores de los diálogos apreciativos el punto de partida, como ocurría con una parte de los detentadores del modelo circular narrativo, es que la realidad es construida por los actores. En este sentido, trabajar en el conflicto es interactuar al nivel de las construcciones mentales de los sujetos. En segundo lugar, los diálogos apreciativos conciben como centro de este actuar a la reflexión; es a través de los procesos de reflexión que las partes pueden vislumbrar sus conflictos tal y como ellos los traen a la mediación. Y, finalmente, ese proceso de reflexión toma un sentido diferente cuando el mediador propugna la búsqueda de imágenes positivas con la intención de resaltar aquello que sí funcionó o funciona entre las partes. Es a partir de estos momentos positivos o apreciativos que el mediador destaca lo que podría ser un primer paso hacia la resolución; si pudieron colaborar antaño, pueden colaborar ahora para salir del conflicto.

A mediação de compromisso surge da reinterpretação do conflito focando no compromisso das partes. "Esta propuesta parte de una particular visión sobre el

\footnotetext{
${ }^{20}$ FRANCO CONFORTI, O. D. Incidencia ... cit. p. 128

21 CALVO SOLER, R. (2012). Programa Compartim de gestió del coneixement. VII Jornada de Prevenció i Mediació Comunitària Escenaris del diàleg. Recuperado el 20 de octubre 2015, de $<$ http://justicia.gencat.cat/web/.content/home/ambits/formacio_recerca_i_docum/biblioteca_i_publicacio ns/publicacions/materials_de_jornades/jornades_formacio_d_acces_lliure/vii_jorn_prev_medi15112012/a lcance_mediacion_raulcalvo.pdf>
} 
conflicto, al que considera desde dos enfoques distintos, el primero de ello entiende al conflicto como un proceso de desarrollo y la segunda como un complejo adaptativo ${ }^{22,}$. O último modelo apresentado por Oscar FRANCO CONFORTI é o da mediação como resolução de conflitos. Esse modelo surgiu com a publicação do livro "Mediación. Resolución de conflictos sin litigio" de autoria de Jay FOLBERG e Alison TAYLOR. Para os autores ${ }^{23}$ os objetivos da mediação são:

La preparación de un plan (convenios) para el futuro, que los participantes pueden aceptar y cumplir.

La preparación de los participantes para que acepten las consecuencias de sus propias decisiones.

La reducción de la ansiedad y otros efectos negativos del conflicto mediante la ayuda a los participantes para que lleguen a una resolución consensual.

Os autores ${ }^{24}$ entendem, ainda, que a mediação é,

[U]n proceso a corto plazo, no una intervención a largo plazo. Es interactiva, y no interpersonal. Someterse a los rasgos de personalidad y la conducta de los participantes (incluyendo la manipulación, la ira extrema, la withdraw, las luchas de poder), que pueden haber creado los problemas de interacción, pero la personalidad no representa el punto central, a menos que la conducta constituya un obstáculo para el proceso de mediación.

No Brasil, a mediação ainda se encontra em processo de difusão e solidificação, não há leis próprias estabelecendo o que seria e qual a distinção da mesma com relação aos mecanismos já comumente utilizados (conciliação).

O Conselho Nacional de Justiça - CNJ, em sua Resolução $n^{\circ} 125$ dispõe sobre a Política Judiciária Nacional de tratamento adequado dos conflitos de interesses no âmbito do Poder Judiciário e dá outras providências. Essa resolução de 29 de novembro de 2010 é importante pois incumbiu aos órgãos judiciários, o oferecimento de mecanismos de soluções de controvérsias.

O recentíssimo novo Código de Processo Civil, que se encontra em vacatio legis, tendo sido instituído pela Lei $\mathrm{n}^{\mathrm{o}} 13.105$ de 16 de março de 2015, recepcionou as ideias do

\footnotetext{
${ }^{22}$ FRANCO CONFORTI, O. D. Incidencia ... cit. p. 129

${ }^{23}$ FOLBERG, J. y TAYLOR, A. Mediación ... cit. p. 27

${ }^{24}$ FOLBERG, J. y TAYLOR, A. Mediación ... cit. pp. 27-28
} 
CNJ, buscando criar no país uma cultura conciliatória e não de embate como vinha sendo feito nos últimos anos. A instituição dessa cultura da paz vem sendo estimulada através da obrigatoriedade da utilização da mediação e da conciliação, como formas rápidas e eficientes de solução de conflitos, o que, sem dúvidas, exigirá uma reflexão e mudança de postura tanto do Estado-juiz como dos próprios jurisdicionados e auxiliares da Justiça.

Logo no art. $1^{\circ}$ do NCPC há previsão de que os juízes, advogados, defensores públicos e membros do Ministério Público deverão estimular a conciliação, a mediação e outros métodos de solução consensual de conflitos.

O NCPC prevê, ainda, que os tribunais criarão centros judiciários de solução consensual de conflitos, responsáveis pela realização de sessões e audiências de conciliação e mediação e pelo desenvolvimento de programas destinados a auxiliar, orientar e estimular a autocomposição (art. 165).

Não obstante o Código não traga de forma expressa o conceito de mediação, o fato de destacar a distinção entre os institutos (conciliação e mediação), nos faz concluir que o legislador buscou estabelecer a necessidade de utilização de técnica extrajudicial transformativa.

O projeto de Lei - PL que deu origem ao NPCP, já previa a implementação da mediação como uma das fases do processo judicial. Referido projeto define a mediação em seu art. $2^{\circ}$, como sendo "atividade técnica exercida por terceira pessoa, que escolhida ou aceita pelas partes interessadas, as escuta e orienta com o propósito de lhes permitir que, de modo consensual, previnam ou solucionem conflitos", tal definição esclarece alguns pontos que merecem destaque no ato de mediar. Esses pontos são: a existência de uma terceira pessoa imparcial ao conflito, porém com formação própria para media-lo, a função primordial de incentivar uma posição dialética entre as partes para que as próprias possam chegar a uma solução satisfatória, o que diminuirá as chances desse conflito ser aceso novamente, ou que a decisão final seja descumprida, e principalmente, a tentativa de construção de consenso entre as partes, de forma que esse consenso seja mantido por elas.

O PL de $n^{\circ} 4827 / 98$, substituído pelo de $n^{\circ} 94$ em 2002, tinha por objetivo instituir a mediação obrigatória e previa a possibilidade da mediação de conflitos de qualquer matéria, desde que essa admita outras formas de solução de controvérsias (conciliação, 
transação ou acordo), o que nos parece ter sido acolhido de maneira genérica pelo NCPC.

Estando cientes da conceituação da mediação e do atual estágio desta no ordenamento jurídico brasileiro, iremos tecer alguns comentários referentes aos objetivos e princípios deste instrumento de solução pacífica de controvérsias.

\subsection{Objetivos}

São inúmeros os objetivos pretendidos pela mediação, no entanto, alguns se destacam por sua relevância. Dentre os objetivos primordiais, podemos citar a busca pelo acesso à justiça, resolução pacífica e não adversarial de conflitos, paz social, ressignificação de valores pelas partes envolvidas, prevenção de futuros conflitos, inclusão social, dentre outros.

Portanto, a mediação tem como fim precípuo a inserção de uma cultura de diálogo, que deverá substituir a tão difundida cultura do conflito. Luis ALBERTO WARAT, explana a necessidade de uma solução profunda, advinda das próprias partes, a qual será calcada em um sentimento natural e sólido:

\footnotetext{
"Os homens da ciência geralmente se escondem detrás dos discursos de verdade para desperdiçar suas vidas. São verdades que têm cheiro de morte. Os homens sábios procuram que nós encontremos as respostas na vida, que a vida responda por nós. Os homens da ciência precisam das instituições para pensar. Todos os homens da ciência vivem nas instituições, não na vida. Muitos outros os imitam, confundem suas funções com suas próprias pessoas (exemplos: juízes, promotores, professores) $" .25$
}

É válido salientar que o autor não quer menosprezar o conhecimento científico, mas somente tecer críticas à cultura adversarial tão propagada pela sociedade contemporânea. Em nome de uma verdade absoluta que os epistemólogos, psicólogos, e outros cientistas já puderam provar não existir, a maioria das pessoas não enxergam os conflitos afundo, mas buscam tão somente a quantificação das soluções, sem levar em consideração que muitos acordos são descumpridos exatamente por não haverem sido tratados de maneira correta, em nome daquilo que chamam de ciência, e que na seara

\footnotetext{
${ }^{25}$ ALBERTO WARAT, L. O ofício ... cit. p. 20
} 
jurídica, em especial, no poder judiciário são por demais influenciados por um positivismo exacerbado.

\subsection{Princípios}

Se verificarmos em um dicionário o significado da palavra princípio, veremos que se apresenta como o momento ou local onde algo tem origem, é a causa primária de determinada coisa, é um preceito, uma regra. A sua titulação no plural, princípios, possui como significação as "proposições diretoras duma ciência"26. Assim sendo, convém analisar, ainda que de maneira sumária, as proposições, os preceitos norteadores da mediação, sendo essas proposições a base fundamental deste mecanismo.

Dentre os principais princípios, aqueles que são aceitos por todas as correntes, podemos citar: a liberdade das partes, ausência de competitividade, poder de decisão advindo das partes, participação do terceiro imparcial, competência do mediador, informalidade e confidencialidade do processo.

Por liberdade das partes podemos entender a autonomia dos conflitantes em buscar e utilizar esse meio de solução, para que essa autonomia seja respeitada se perfaz importante que as partes tenham plena consciência do que representa uma mediação.

A ausência de competitividade consiste na boa-fé dos litigantes, embora exista um problema entre eles ambos estão ali para solucioná-lo da melhor maneira possível e não para buscar uma situação de vantagem perante o outro.

O poder de decisão é inerente ao processo de mediação, é o fio condutor de todo esse processo. Aqui reside uma das principais características da mediação, pois as partes é que chegarão à solução, não havendo qualquer interferência do mediador que será apenas um coadjuvante, auxiliando, facilitando o caminho para a paz.

Considerando o princípio do poder de decisão das partes, que está intimamente ligado ao princípio da liberdade, entendemos que as partes não estão obrigadas a fazer acordo, mas estão convidadas a dialogar em prol de solucionar o conflito. Nesse princípio, não existe imposição de um terceiro para solucionar o conflito; cada parte é que tem o poder de decidir. Entretanto, para alguns conflitos ambientais, a autonomia da parte é reduzida, não estando os gestores, na sua

\footnotetext{
${ }^{26}$ HOllandA FerreirA, A. B., Novo Dicionário Aurélio da Língua Portuguesa. 2. ed., Nova Fronteira, Rio de Janeiro, 1986. p. 442
} 
maioria, gestores públicos, vinculados às decisões das partes. O resultado da mediação destina-se a orientar a decisão do Poder Público, que, obrigado a realizar audiência pública para consulta à comunidade, o faz por meio da mediação de conflitos $^{27}$.

A imparcialidade e competência do mediador são princípios basilares não apenas na mediação, mas também em outras formas de solução de litígios, como acontece até mesmo no Poder Judiciário. Para se alcançar uma solução justa é necessário e mais seguro que o mediador ou julgador, a depender do caso, seja uma pessoa imparcial além de ser uma pessoa capacitada para o ato, no caso do juiz, este deverá ser um juiz natural, ou seja, aquele que exerce o cargo de acordo com as exigências legais e normas de competência previstas na Constituição Federal, e o mediador, deve ser um indivíduo com formação especifica para solução de conflitos, pois somente assim trará confiança às partes e realizará um trabalho eficaz.

Por fim, temos a informalidade e confidencialidade do processo, princípios que se destacam como qualificadores da otimização do processo de mediação. Embora a Constituição Federal preveja como direito fundamental de todos a razoável duração do processo, sabemos que os processos acabam por se eternizar nas prateleiras do judiciário, sendo a mediação desprovida de maiores formalidades e burocracias, e pautada na informalidade, torna-se mais célere, fazendo com que a justiça esteja mais próxima da sociedade. Quanto à confidencialidade, essa consiste no dever ético do mediador de manter os dados do conflito mediado em sigilo, como forma de dar maior credibilidade e confiança ao instrumento.

O novo Código de Processo Civil estabelece como princípios norteadores da conciliação e mediação os princípios da independência, da imparcialidade, da autonomia da vontade, da confidencialidade, da oralidade, da informalidade e da decisão informada, destacando a necessidade de se manter o sigilo do ato negocial, bem como a possibilidade de liberdade no estabelecimento de regras negociais (art. 166, Lei $\mathrm{n}^{\mathrm{o}}$ $13.105 / 2015)$.

\footnotetext{
${ }^{27}$ BRAGA MARTINS, D. y DO CARMO BARROS, M., "A mediação como mecanismo de solução de conflitos ambientais e efetivação do princípio da participação social", Queiroz Caúla, B., Braga Martins, D., Menezes Albuquerque, N. y Moura do Carmo, V. (org.), Diálogo Ambiental, Constitucional e Internacional. v. 1, Premius, Fortaleza, 2013. p. 152
} 
Portanto, como vimos, a principal distinção entre os métodos alternativos e a mediação reside no fato de que esta, além de solucionar o conflito, busca (re)criar vínculos entre as partes, transformar e prevenir os conflitos. ${ }^{28}$

Em geral, verifica-se uma série de pontos de interseção entres os diversos meios alternativos. Citando brevemente alguns desses pontos, teremos: a interferência de um terceiro imparcial, a concordância recíproca das partes em tentar encontrar a solução, a ausência de formalidades processuais encontradas no judiciário (ainda que se refira a negociação realizada perante o poder judiciário, o tramite burocrático quando da homologação de um acordo é bem menos complexo). Em que pese essas semelhanças, as diferenças existem e merecem ser observadas sob pena de não conseguirmos solucionar os conflitos adequadamente.

Um dos pontos apontados pelos defensores do modelo de Harvard como a principal divergência entre a mediação e os demais meios é a maneira como é posto fim ao problema. Isso porque na arbitragem, na conciliação e na negociação uma das partes deverá "ceder", o que poderá ocasionar o sentimento de perda, por menor que seja, enquanto que na mediação o intuito final é a ressignificação de valores e a consequente construção de consenso, de forma que todos os envolvidos sairão satisfeitos e com o sentimento de ganho.

É importante explanar, ainda, o porquê da escolha específica da mediação e não de outros métodos para a solução dos conflitos ora analisados, embora desde já se esclareça que todos podem ser utilizados desde que adequados ao tipo de conflito, entendendo-se, porém, que a mediação seria o meio mais adequado para os conflitos ambientais. Iniciaremos a explicação através da análise crítica dos demais métodos expostos, com o objetivo de demonstrar a ineficiência destes diante da mediação socioambiental, entendida está como instrumento de efetivação do direito ao meio ambiente ecologicamente equilibrado, e não como simples meio de solução de conflitos.

Dentre os meios alternativos analisados a negociação seria a que mais se aproxima dos objetivos buscados pela mediação, isso porque, sendo as próprias partes que chegam a uma solução para conflito é perfeitamente possível que através de diálogos possam chegar a uma construção de consenso por meio da negociação. Contudo, a dificuldade

\footnotetext{
${ }^{28}$ MAIA DE MORAIS SALES, L., Mediare: um guia prático para mediadores. 3. ed. GZ, Rio de Janeiro, 2010. p. 33
} 
de se aplicar a negociação para as demandas ambientais encontra-se em dois fundamentos: o primeiro reside na existência de múltiplos sujeitos, o que conforme se verá a seguir dificulta uma negociação plausível e o encontro de um consenso; em segundo, verificamos também a existência de uma grande discrepância entre o poder de conhecimento e de persuasão de uma das partes sobre as outras, fazendo com que os membros da sociedade civil saiam prejudicados pelo alto poder econômico, técnico ou científico dos demais atores, desta forma esse meio acaba não sendo favorável à resolução dos problemas de cunho ambiental.

A Arbitragem tem de pôr fim a finalização de lides que envolvem a discussão de bens ou direitos disponíveis, o que para alguns poderá ser um entrave na solução de problemas ambientais, posto que o meio ambiente, bem de uso comum do povo e direito difuso, não pode ser considerado como um bem disponível, ainda que sob seu contexto de "microbem"29, onde é possível uma determinada "apropriação" por parte de particulares. Aliado a este problema, há outros fatores que são desfavoráveis, como o custo elevado, a necessidade de concordância de todos os envolvidos dentre outros.

Quanto à conciliação, dentre os métodos até então apontados, ela seria a que melhor se encaixa na solução de controvérsias ambientais, não havendo maiores entraves na sua utilização, entrementes, a mediação ainda se revela a melhor opção, pois não havendo a construção de consenso na conciliação, mas tão somente a finalização da contenda através de um acordo, o mesmo poderá ser descumprido, ou ainda permitirá que surjam futuros conflitos envolvendo as mesmas partes e os mesmos objetivos, pois não terá havido uma construção de consenso, onde as partes teriam compreendido, inserido e aceito a solução em seu cotidiano, ou seja, não terá ocorrido uma significação de valores capaz de modificar as partes e consequentemente as causas do conflito.

É válido ressaltar que não se pretende aqui fazer uma valoração de mérito, indicando que um dos meios seja melhor que outro, mas conforme ensina Lilia MAIA DE MORAIS SALES, a questão consiste em "que não devemos fazer comparações de mérito entre esses mecanismos, tendo em vista que um não é melhor que o outro, apenas alguns se revelam mais adequados a determinados tipos de conflitos". ${ }^{30}$ Entretanto, a

\footnotetext{
${ }^{29}$ O conceito de "microbem" pode ser definido como a consideração do meio ambiente através de seus elementos corpóreos, individualizáveis, ou seja, as florestas, os rios, a propriedade de valor paisagístico, as águas, dentre outros. Válido salientar que não se trata da noção unitária s de macro de meio ambiente, mas das entidades singulares que o compõem.
}

${ }^{30}$ MAIA DE MORAIS SALES, L. Mediare ... cit. p. 33 
necessidade de incentivo de uma sociedade que promova valores que sejam mais que meras acomodações setoriais é uma realidade, razão pela qual buscamos formas que possibilitem a difusão de valores éticos ambientais, acreditando que a mediação possa ser uma dessas formas, por acreditarmos ser o mais adequado a essa espécie de conflito.

\section{CONFLITOS SOCIOAMBIENTAIS}

Inicialmente convém definirmos o que seria conflito. Para somente então tentarmos caracterizar, ou ao menos delimitar as distinções que envolvem os conflitos ambientais.

Ao consultar um dicionário, verificamos que a palavra conflito possui como significados: luta; combate; guerra; desavença e discórdia. ${ }^{31}$ Muito provavelmente o senso comum baseia-se nessas significações para formular o ideário negativo dos conflitos, enxergando-os como algo ruim. Para Waldir SINISTERRA RESTREPO,

El conflicto como tal no es algo nuevo, es inherente en las personas, este existe desde el mismo origen de las relaciones humanas y en especial cuando se crean las comunidades de individuos, naciendo por supuesto situaciones que se le contraponen entrando en oposición o desacuerdos por que sus posiciones e intereses, deseos, necesidades no son compatibles o se perciben como tal entrando en juego las emociones y sentimientos donde dichas relaciones pueden salir fortalecidas o deterioradas de acuerdo a como se enfrente el proceso de resolución del Conflicto $^{32}$. [Sic]

Segundo Isabel ARACELI HOYO SIERRA,

La Psicología Social define el conflicto - toda clase de conflicto- como la percepción de incompatibilidad entre el objeto que una de las partes del conflicto pretende y el objetivo de la otra parte de tal modo que cada una de ellas mantiene la idea de que la pretensión de la otra parte le resulta nociva. Para que exista un conflicto no es precisa la existencia de una relación previa entre las partes, bastando el vínculo que se establece entre ellas cuando una de ellas percibe las pretensiones de la otra como perjudicial para sus intereses. Aunque, por supuesto, los conflictos también son muy frecuentes entre personas que mantienen diversos tipos de relaciones y, por tanto, se da entre ellas una interdependencia. En ambos

\footnotetext{
${ }^{31}$ HOLLANDA FERREIRA, Novo Dicionário... p. 138

${ }^{32}$ SINISTERRA RESTREPO, W. "Mediación Comunitaria”, Souto Galván, E. (dir.), La mediación: un instrumento de conciliación, Editorial Dykinson, Madrid, 2010. p. 356
} 
casos, la virulencia del conflicto va a depender de la magnitud del interés que las partes consideran perjudicado ${ }^{33}$.

Trinidad SAMPER nos recorda que o conflito normalmente se desenvolve "desde el momento que se percibe que el otro representa una amenaza, comenzando un proceso destinado a dominar, controlar, reducir o destruir dicha amenaza "34. Inegável o caráter adversarial inerente aos conflitos, mas somente a "luta" por determinados interesses ou posições não deve ser visto como algo negativo, isto porque, o homem, como animal eminentemente social, estará sempre adstrito aos conflitos, sendo esses, verdadeiros vetores da evolução da sociedade humana. Oportuna a observação de Isabel ARACELI HOYO SIERRA de que,

La consideración de estas dos variables del conflicto: la del tipo de interés que se juzga perjudicado, y la del grado de interdependencia mutua entre las partes del conflicto, nos permite ya entrever que la solución del conflicto va a variar, dado que, sin duda, resulta más sencilla la resolución de un conflicto entre partes no interdependientes que entre partes interdependientes, y más sencilla la resolución del conflicto cuando el asunto a dirimir concierne a bienes materiales que cuando afecta a la autoestima de una o ambas partes, lo que sin duda afecta a la idoneidad de la adopción de un tipo u otro de procedimiento para la resolución dicho conflicto ${ }^{35}$.

Entendendo o conflito como algo inerente à humanidade é preciso que se encontre meios de pacificá-los para que a evolução decorrente destes episódios sejam as mais brandas e construtivas possíveis. Portanto, o conflito e a insatisfação tornam-se necessários para o aprimoramento das relações interpessoais e sociais ${ }^{36}$, sendo instrumento de aprimoramento social. Devemos ter em mente que não é o conflito que é ruim, pelo contrário, ele é necessário. A sua boa ou má administração é que resultará em desfecho positivo ou negativo ${ }^{37}$.

\footnotetext{
${ }^{33}$ ARACELI HOYO SIERRA, I., "La idoneidad de los métodos alternativos de solución de conflictos", GONZALO QUIROGA, M. (dir.). Métodos alternativos de solución de conflictos: perspectiva multidisciplinar, Universidad Rey Juan Carlos/Editorial Dykinson, Madrid, 2006. p. 356

${ }^{34}$ BERNAL SAMPER, T., La mediación en escena, Editorial EOS, Madrid, 2012. p. 21

${ }^{35}$ ARACELI HOYO SIERRA, I., “La idoneidad ...” cit. p. 357

${ }^{36}$ MAIA DE MORAIS SALES, L. Mediare ... cit. p. 1

${ }^{37}$ MAIA DE MORAIS SALES, L. Mediare ... cit. p. 2
} 
Neste ínterim, temos que compreender as peculiaridades envolvidas nos conflitos socioambientais, para que possamos extrair desses as melhores soluções e para que estas sirvam de instrumentos de aprimoramento.

Caracterizados por serem conflitos de extrema urgência e importância coletiva, os conflitos ambientais devem ser considerados como prioritários dentro dos sistemas jurídicos, ou seja, a previsão de meios de solução de conflitos desta natureza deve ser tratada pelos ordenamentos jurídicos como bens relevantes e, portanto, é necessário que prevejam formas eficazes de solucionar as contendas.

No entanto, embora o ordenamento jurídico brasileiro seja repleto de normas de caráter ambiental, as mesmas são constantemente violadas, gerando uma verdadeira contradição entre a formalidade legal e a práxis. Embora haja leis tendentes a instituir a celeridade no âmbito processual, as lides ambientais ainda são caracterizadas por disputas políticas e ainda ficam à mercê das subjetividades dos magistrados, herança de uma sociedade completamente exploratória, posto que desde a época colonial o poder e o judiciário brasileiro vão de encontro à legislação ambiental. Isso por que: "Os sistemas foram alicerçados em uma visão clássica de desenvolvimento e crescimento econômico, fundado em um industrialismo totalmente agressivo aos recursos naturais. Nestes modelos, a regra é o acumulo de capital e produção de riqueza, sendo ignorada a preservação dos recursos naturais, como elemento de uso limitado" ${ }^{\text {38. }}$.

Sendo a primeira constituição do mundo a trazer em seu bojo capitulo próprio reservado a tutela jurídica dos bens ambientais, o ordenamento jurídico brasileiro foi considerado de vanguarda na temática ambiental. Diversas leis ordinárias também regulam a matéria, mas a inaplicabilidade dessas normas torna o sistema falho e ineficaz na proteção ambiental. Mesmo com esse aparato legislativo em prol da defesa ambiental o que se vê é um desrespeito com a natureza tanto por parte da sociedade como dos órgãos ambientais. Outro problema que se constata é que, ao se chegar ao judiciário, depara-se com atitudes conservadoras de alguns juízes, sem qualquer conhecimento lógico-jurídico, o que acaba por prejudicar ainda mais o meio ambiente.

\footnotetext{
38 MORATO LEITE, J. R., Dano ambiental: do individual ao coletivo extrapatrimonial, Revista dos Tribunais, São Paulo, 2000, p. 23
} 
Sobre a possibilidade de aplicação da mediação em conflitos desta natureza, trazemos os ensinamentos de Lilia MAIA DE MORAIS SALES, ao avaliar quais os tipos de conflito podem ser mediados aduz que:

Diante da definição de mediação e dos objetivos desse processo, percebe-se que ela pode ser instrumento de resolução para vários tipos de conflito. Acredita-se, na verdade, que a mediação pode ser utilizada para quase todo o tipo de antagonismo, esclarecendo-se, porém, que determinadas controvérsias, para ter validade jurídica, devem ser enviadas para o Poder Judiciário ou formalizadas, quando possível, em contrato. Ainda não existe legislação especifica que trate sobre o tipo de conflito que pode ser objeto de mediação. Assim, cabe verificar o que o Direito vigente permite ser objeto de mediação ${ }^{39}$.

E a autora continua citando os conflitos plausíveis de serem mediados, entre eles: questões familiares, questões cíveis, conflitos envolvendo questões comerciais, direito do consumidor, conflitos escolares, de vizinhança e por fim, os conflitos ambientais. Depreende-se dessa explanação, ser plenamente possível a mediação de conflitos socioambientais, sendo esses conflitos, via de regra, formados por vários atores sociais, demonstra-se a existência de uma relação continuada e inter-partes, o que denota que além de possível a mediação é aconselhada como um instrumento de acesso à justiça.

\section{A MEDIAÇÃO DE CONFLITOS SOCIOAMBIENTAIS}

Conforme visto, a temática ambiental e a necessidade de preservação e recuperação dos bens ambientais, requerem meios de soluções de conflitos hábeis a tornar a proteção legal existente efetiva, bem como pôr fim às lides de maneira rápida e eficaz. Sendo a mediação um instrumento de solução pacifica de conflitos, o que se pretende propor é a utilização da mediação como forma dinâmica de solucionar conflitos ambientais. Para tanto, é que foi necessário apresentar as características desses conflitos, para somente então verificarmos a possibilidade de solução desses através da mediação.

Inicialmente fazemos um apanhado dos fatores negativos que poderiam afastar a aplicação desta forma de solução de conflitos, rebatendo-os com os fatores positivos, para ao final, concluirmos pela possibilidade e eficácia da mediação socioambiental.

\footnotetext{
${ }^{39}$ MAIA DE MORAIS SALES, L. Mediare ... cit. p. 75
} 


\section{Fatores negativos à mediação ambiental}

Procederemos com uma breve exposição de alguns dos fatores que são considerados como verdadeiros empecilhos à utilização da mediação socioambiental, para ao final desmistificar essas ideias, expondo que, na realidade, a má compreensão desses fatores é que acarreta essa errônea interpretação que acaba por afastar a aplicação da mediação.

\subsection{Grande quantidade de atores sociais}

Uma característica própria desse conflito está na presença de uma grande quantidade de atores sociais envolvidos. Pode-se citar de maneira breve a existência de vários polos diretamente relacionados: sociedade civil; governos (União, Estados e Municípios); organizações não-governamentais; poder público, aqui compreendido o Ministério Público (como fiscal da lei e defensor dos direitos difusos e coletivos) e o Poder Judiciário; órgãos ambientais; mercado (empreendedores); a mídia, dentre inúmeros outros a depender do conflito propriamente considerado. Para Flavia ROSEMBUJ ${ }^{40}$ :
Los conflictos ambientales suelen ser por naturaleza multipartes ya que normalmente el número de actores implicados es más de dos. En estos conflictos se ven involucrados diferentes actores sociales como administraciones públicas, organismos no gubernamentales, grupos de vecinos, empresas, etc. Debido a que el resultado de estos conflictos afecta a un número elevado de personas, los procesos de mediación están impregnados de un alto nivel de exposición pública y suelen ser muy controvertidos. En los conflictos multipartes no sólo encontramos a las partes definidas como aquellos actores afectados de forma directa por la situación conflictiva sino también a los llamados "grupos de interés" en la problemática.

Além da quantidade de atores envolvidos devemos ter em mente que a natureza desses também é distinta, havendo desde profissionais envolvidos na lide a cidadãos sem qualquer conhecimento técnico. Daí destaca-se a importância do papel do mediador, que deverá ajudar na busca por interesses em comum, bem como identificar aqueles que são convergentes e divergentes.

\footnotetext{
${ }^{40}$ ROSEMBUJ, F., "Nuevas formas de acción en la protección del ambiente: la negociación de la administración con el contaminador y la mediación de conflictos ambientales", GONZÁLEZ-CAPITEL, C. (coord.), Mediación x 7, Atelier, Barcelona, 2001. p. 150
} 
De maneira contrária, há quem entenda que a grande quantidade de envolvidos deve ser vista como um fator de legitimação do estado democrático. Em artigo destinado a descrever as formas de diminuição dos riscos ambientais envolvendo áreas de risco, Ícaro CUNHA aponta a importância da participação social dos próprios envolvidos no conflito como um meio eficaz de solução e segurança. Nas palavras do autor:

\begin{abstract}
A evolução dos controles ambientais coloca em destaque a necessidade de garantir a segurança das comunidades, tarefa que, - - a experiência indica - exige o acesso democrático à informação e a participação dos vários grupos e atores sociais. Os grupos expostos ao risco em função de seus locais de moradia muitas vezes são parte dos segmentos mais segregados das cidades, aqueles que se instalaram junto a dutos e tanques materiais perigosos justamente porque não eram reconhecidos como parte da cidade organizada. O desafio passa a ser construir sua participação, o que coloca em destaque a questão de negociar conflitos. A própria Petrobras vem acumulando interessantes experiências em parcerias com organização nãogovernamentais que fazem o levantamento e desenvolvem entendimentos com comunidades que habitam faixas de dutos da empresa, em diferentes pontos do país, em trabalhos que vão-se tornando fonte de interesse e aprendizado ${ }^{41}$.
\end{abstract}

\title{
1.2. Limites formais - impossibilidade de interferência nas disposições legais
}

A legislação ambiental brasileira é conhecida por possuir um ordenamento moderno no que concerne a temática ambiental, sendo um dos países em destaque no cenário internacional na luta pela preservação ambiental, além de ser o possuidor da maior reserva de água potável e da maior floresta mundial, possui um enorme apanhado de normas tendentes à proteção desses bens de valor incalculável. Por haver inúmeras normas e todas com limites formais quanto ao uso e ao gozo desses bens, há quem entenda não ser possível a solução dos conflitos dessa natureza, por não haver margem aos conflitantes, devendo, portanto, as normas serem respeitadas.

Quando nos referimos aos bens ambientais, bem de natureza difusa, assim considerados pela própria Constituição Federal, em seu art. 225, deve-se ter em mente que todo e qualquer meio de solução de conflito deverá ter estrita observância aos ditames legais. $\mathrm{Na}$ realidade, essa obediência aos limites impostos por lei deve ser observada em todos

\footnotetext{
${ }^{41}$ CUNHA, Í., "Insalubridade e Conflito ambiental: risco e cidadania". Revista de administração pública. Rio de Janeiro: Fundação Getúlio Vargas, v. 37. n. 02, 2003, p. 453
} 
os conflitos que são submetidos a alguma forma de conciliação (entendida não como espécie de meios pacíficos, mas como forma de se buscar o consenso), pois somente assim haverá a validação jurídica dos acordos mediados.

Essa limitação legal é vista por alguns como um fator negativo quando da mediação de conflitos ambientais, posto que estaria a delimitar o âmbito de atuação do acordo, entretanto, deve-se ter em mente que, a contrario sensu a observância do que está previsto em lei representa um fator a mais para a efetividade do acordo e também, por via indireta, no respeito ao ordenamento jurídico pátrio, tendo-se, assim, a efetiva proteção ao meio ambiente. É valido ressaltar que sendo um bem metaindividual, difuso e de titularidade coletiva, ainda que legalmente possível, não seria justo uma transação que pudesse ferir o direito de terceiros ao acesso ao meio ambiente ecologicamente equilibrado.

Além disso, é válido relembrarmos que, em todas as searas onde os conflitos são levados à solução por meios alternativos, deverá haver o respeito aos limites legais, não podendo as partes transigir fora de esses limites. A mediação familiar, escolar, empresarial ou em qualquer outra área deverá respeitar as leis existentes sobre a matéria sob pena de realizar acordos inválidos e sem qualquer validade e eficácia no mundo jurídico, da mesma maneira irá ocorrer com os conflitos em âmbito ambiental.

\subsection{Complexidade dos temas envolvidos}

Os conflitos ambientais são caracterizados pela interdisciplinaridade, distinção própria dos problemas dessa natureza, isso porque além de envolverem inúmeras ciências naturais, a depender da problemática, envolvem, ainda, questões econômicas, culturais, políticas e sociais.

Tendo por exemplo um conflito envolvendo a disputa por terras de uma reserva florestal entre uma empresa mineradora e uma comunidade indígena, esse caso poderá envolver além de problemas de ordem jurídica (consulta prévia), econômica (sustentabilidade versus investimentos), social, cultural e política, problemas de ordem natural, que envolverá conhecedores de biologia, geografia, geologia, dentre inúmeros outros. Nesse 
caso, sem a utilização da mediação existe o risco de polarização e de escalada dos conflitos $^{42}$.

Por tais razões, os problemas ambientais são considerados complexos, o que poderia ser uma limitação à resolução dos mesmos através da mediação, apesar da natureza complexa desses conflitos exigir a presença de especialistas em determinadas questões, isso por si só não afasta a possibilidade de utilização da mediação, para tanto basta que haja um representante de determinada área (quando for imprescindível a presença deste), o que poderá tornar a solução ainda mais sólida e sem possibilidade de futuras impugnações quando envolver aspectos técnicos. Ademais, em alguns casos, o fortalecimento das fragilidades é um caminho para consolidar o respeito mútuo ${ }^{43}$.

\subsection{Ausência de relação continuada entre os envolvidos e diferença de poder entre as} partes

Podemos ter a falsa impressão que nos conflitos socioambientais, não haveria uma relação continuada entre os envolvidos na lide, o que poderia culminar na desqualificação da mediação como método hábil a solução de conflitos desta estirpe. Entretanto, é válido salientar alguns pontos que podem permanecer obscuros em uma análise superficial do problema.

O fato da mediação, na atualidade, ter ganhado maior relevância com sua aplicação na seara familiar, não significa que seja hábil em solucionar apenas essa espécie de conflito. Como visto alhures, diversas outras causas podem ser sanadas através da mediação. Um grande passo já é o entendimento de que se pode chegar a soluções pacíficas, sem uma posição adversarial, como geralmente é disseminado na cultura brasileira. $\mathrm{O}$ segundo passo é definir qual método mostra-se mais adequado ao conflito.

Os conflitos ambientais por apresentarem uma série de atores envolvidos geram certo desconforto quando da aplicação da técnica mediativa. No entanto, a questão está na definição do porquê da utilização desse método em conflitos dessa natureza, quando

\footnotetext{
${ }^{42}$ SCHILLING-VACAFLOR, A. y FLEMMER, R. El derecho a la consulta previa: Normas jurídicas, prácticas y conflictos en América Latina. Deutsche Gesellschaft für Internationale Zusammenarbeit (GIZ) GmbH, Eschborn, Alemania, 2013. p. 7

${ }^{43}$ HUFF THEODORO, S.; FIGUEIREDO CORDEIRO, P. M. y BEKE, Z., (2004) Gestão ambiental: uma prática para mediar conflitos ambientais. Anais do II encontro associação nacional de pós-graduação e pesquisa em ambiente e sociedade - ANPPAS. Indaiatuba: São Paulo, 2004. Recuperado no día 10 de mayo de 2015, de http://www.anppas.org.br/encontro_anual/encontro2/GT/GT05/suzi_theodoro.pdf.
} 
supostamente não há uma relação continuada entre os envolvidos. Ora, essa visão é equivocada e acaba por ignorar um dos aspectos primordiais envolvendo os conflitos ambientais, qual seja, a relação homem-natureza. Como afirmar não existir relação continuada entre as partes, sendo o meio ambiente, em todas as acepções do termo (natural, artificial, cultural e do trabalho), o habitat de todos os seres humanos?

Ainda assim, é preciso salientar que a depender do conflito haverá sim relações continuadas entre as partes, pois sempre haverá uma estreita ligação entre vizinhos, população e governo, consumidor e investidores e assim por diante. O que ocorre é que, em geral, a ideia de relação continuada é reduzida às relações familiares ou socioafetivas, não sendo correta essa lógica. Assim, também resta afastado, ou ao menos mitigado, o fator negativo ora analisado.

\section{Fatores positivos à mediação ambiental}

Agora que já expusemos os principais fatores considerados como entraves à mediação ambiental, faremos um apurado daqueles que por outro lado são tidos como grandes qualidades dessa espécie de mediação, ainda pouco difundida no Brasil. Ao final, poderemos comparar os prós e contras para então nos posicionarmos favoravelmente ou não à aplicação da mediação ora proposta.

\subsection{Celeridade no processo de negociação}

Uma das grandes preocupações dos processualistas contemporâneos é a demora do judiciário e a busca por soluções plausíveis para este problema. Neste diapasão, a Constituição Federal de 1988 sofreu uma mudança através da Emenda Constitucional $n^{\circ}$ 45 de 08 de dezembro de 2004, que institui um direito até então implícito aos litigantes, mas que, visando dar um caráter de maior solidez, foi acrescido a nossa Lex Maior, que é o direito à duração razoável do processo, previsto em seu art. $5^{\circ}$, LXXVIII.

Antes mesmo da implementação e mesmo após ela, os processualistas estudam meios de tornar o judiciário mais célere, pois somente assim poderemos ter uma justiça eficaz e que possa satisfazer as partes. Neste contexto, foi aprovada no Congresso Nacional a proposta do novo código de processo civil, tendo como uma das principais preocupações a diminuição do lapso temporal dos processos. 
Assim, podemos perceber que uma das grandes problemáticas do poder judiciário brasileiro se encontra no lapso temporal de resolução dos processos. Na contramão deste problema, temos a mediação, como um processo célere e eficaz, que traz plena satisfação as partes, além de ser um auxilio no "desafogamento" do judiciário.

\subsection{Decisões mais econômicas}

Não podemos nos esquecer do fator econômico, que envolve as disputas que vão parar no judiciário, além do desgaste emocional das partes que passam anos envolvidas em um conflito, alimentando um sentimento de rancor, ódio e desavenças, os processos levados ao Poder Judiciário são dispendiosos envolvendo inúmeros gastos, desde a contratação dos advogados, até o pagamento de pericias, custas judiciais dentre outros. Sem dúvidas, a mediação é um processo mais econômico para ambas as partes, pois o único gasto envolvido no processo será o da instituição e/ou mediador que irá trabalhar no caso, embora tais valores possam variar conforme o caso e a instituição, ainda assim não podemos compará-los aos custos de um processo judicial que se arrasta durante anos.

\subsection{Legitimação da decisão e consequente cumprimento do acordo}

Através de resultados mutuamente satisfatórios haverá um alto nível de cumprimento dos acordos. Tânia ALMEIDA discorre sobre o tema:

A autoria das soluções devolve aos mediandos o controle do processo decisório sobre suas próprias vidas e possibilita que a solução eleita atenda a seus reais interesses, necessidades e valores. Autores cuidam do que criam, o que torna o cumprimento do acordado na Mediação uma conseqüência natural e uma ação pautada no compromisso entre os envolvidos ${ }^{44}$.

As partes, como únicas responsáveis pelas soluções encontradas, sentem-se incluídas e passam a sentir-se valorizadas por haverem sido importantes para a solução do problema. O sentimento de "ganha-ganha" comumente oriundo do processo de mediação auxilia na manutenção dos acordos, pois como vimos, é muito mais

\footnotetext{
${ }^{44}$ ALMEIDA, T., (2005). Mediação de conflitos: Um meio de prevenção e resolução de controvérsias em sintonia com a atualidade. Recuperado no día 33 de abril de 2015, de http://www.mediare.com.br/08artigos_13mediacaodeconflitos.html.
} 
improvável que alguém que tenha feito determinada coisa venha a destruí-la, da mesma maneira ocorre com a decisão tomada no processo, havendo ambas as partes ressignificado valores e construído um consenso, ambas lutaram pela manutenção da palavra dada.

Sobre a construção de consenso, SUSSKIND e ZION assim o definem: "Consensusbuilding enhances democratic practice by involving those directly affected by decisions in the process of deciding what to do. As a consequence, such decisions are easier to implement ${ }^{, 45}$.

\subsection{Decisões pró meio-ambiente}

No que diz respeito à relação homem-natureza a mediação pode ser vista como um instrumento de auxílio na preservação ambiental. Isso decorre do fato de que a mediação tendo por objetivo auxiliar as partes na avaliação dos seus valores e a partir de então buscar os pontos de interseção de maneira a construir um consenso, sem sombra de dúvidas buscará alcançar os ideais ambientais, isso porque as leis também deverão ser observadas, de maneira tal que a construção dos consensos envolvendo as questões ambientais terão por fim soluções em prol da natureza e de maneira a satisfazer o maior número de envolvidos, prevalecendo as ideias ambientais sobre outras visões que não pró-meio-ambiente.

\subsection{Efetivação de princípios ambientais}

Diretamente relacionada ao item acima, a efetivação dos princípios ambientais também será alcançada em razão da observância das normas ambientais em vigor. Além disto, outros princípios, por si só, serão efetivamente respeitados em razão do próprio processo de mediação. Explicaremos como. Dentre esses, podemos citar o princípio democrático, que se desdobra em dois outros: o direito à informação e a participação popular, Sendo a mediação um processo inclusivo onde as partes atuam diretamente, a

\footnotetext{
${ }^{45}$ SUSSKIND, L. y ZION, L., (2002) Can America's democracy be improved? Draft Working Paper of the Consensus Building Institute and the MIT-Harvard Public Disputes Program. 2002, Harvard. Recupera no día 13 de mayo de 2015, de: http:/www.lawrencesusskind.com/wpcontent/uploads/2013/07/Improving-American-Democracy-Negotiation-Susskind-Zion.pdf

Tradução-livre: “A construção do consenso reforça a prática democrática, envolvendo aqueles diretamente afetados pelas decisões no processo decisório. Como consequência, as decisões são mais facilmente cumpridas".
} 
participação democrática de todos os envolvidos resta completamente respeitada. No que concerne ao direito de informação, também haverá uma plenitude de exercício, pois todos os participantes do processo terão acesso as mais variadas informações referentes ao conflito, para que somente então cheguem a um consenso.

Pelo exposto, podemos perceber que embora ainda não seja tão disseminada na cultura jurídica, a mediação, em especial a que ora propomos, que tem por base os conflitos na seara ambiental, mostra-se como um importante caminho na busca da paz social e da preservação ambiental.

Sobre o tema, Celso SIMÃO BREDARIOL salienta a existência de uma doutrina fraca no contexto brasileiro, mas, lembra que no direito comparado esse costume já está disseminado há algumas décadas:

No entanto, a literatura internacional é rica em métodos de apoio à negociação ou sobre a mediação de conflitos. A primeira mediação de conflito nos EUA é relatada por McCormick em 1973, Binghan (1986) avalia uma década de mediação de conflitos ambientais, Amy (1987) faz um estudo crítico da experiência americana de mediação, Susskind (1996) é um entusiasta da mediação. Outros autores, com base na Teoria dos Jogos desenvolvem a análise de confrontos (Howard 1999), a teoria do Drama (Bryant 1998), o hypergame Bennet (1998) e vários outros métodos de apoio à resolução de conflitos ${ }^{46}$.

A utilização da mediação ambiental e de abordagens cooperativas tem sido empregada pelo mundo independentemente do sistema jurídico do país, seja de origem romanogermânica ou common law. O que o mundo parece estar começando a buscar, são ferramentas que desenvolvam políticas e implementem programas e projetos necessários para alcançar uma sociedade, economia e meio ambiente sustentáveis. Isto não pode ser feito com a mesma linha de pensamento com a qual criamos o mundo atual e os problemas com ele relacionados. ${ }^{47}$

\footnotetext{
${ }^{46}$ SIMÕES BREDARIOL, C., (2004) O aprendizado da negociação em conflitos ambientais. Anais do II encontro associação nacional de pós-graduação e pesquisa em ambiente e sociedade - ANPPAS. Indaiatuba: São Paulo, 2004. Recuperado no día 13 de mayo de 2015, de: http://www.anppas.org.br/encontro_anual/encontro2/GT/GT17/gt17_celso_bredariol.pdf.

${ }^{47}$ BERNARDES DE SOUZA, J. R., A audiencia pública e a mediação ambiental no processo de disputas públicas ambientais. Estudo de caso: EIA da Usina termoelétrica de Santa Branca -SP, 2003. 110 f. Dissertação (Mestrado em Engenharia Civil), Campinas, Universidade Estadual de Campinas, 2003. p. 97
} 
Logo, a busca pela paz social como um dos postulados da mediação demonstra a total adequação deste meio de solução de conflitos para com os problemas de cunho ambiental. Portanto, a mediação visa solucionar os embates através de uma visão egológica, ecológica e holística, analisando o problema como um todo interligado a diversos outros fatores. Sobre essa visão holística do direito e dos meios de solução de conflitos:

O holismo propõe uma inscrição do amor nas oportunidades vitais, nos vínculos, nos conflitos, na ética e no direito. No fundo, é uma afirmação de que sem a construção afetiva com o outro, sem a realização do amor, não existe possibilidade de melhorar a qualidade de vida. É necessária uma ecologia do amor, um eco de alteridade que faz do amor condição de ecologia política ${ }^{48}$.

Ou seja, tendo o ser humano como cerne das questões e sendo ele o único responsável pela manutenção ou solução dos problemas, mostra-se necessária a compreensão dos conflitos, para que possamos analisar o equilíbrio do sistema que só irá funcionar se todos os órgãos estiverem em perfeita operação. Diante dessas colocações percebemos que a proposta é de utilização de uma solução pacifica dos conflitos que poderá proporcionar grandes conquistas na seara ambiental. Percebemos, assim, a mediação como fio condutor de acesso a esta justiça.

\section{CONSIDERAÇÕES FINAIS}

Assim, constatamos que a mediação de conflitos garante a concretização de direitos fundamentais, como o acesso à justiça, contribuindo para efetivação do Estado Democrático de Direito. Nesse particular, os recursos não-adversariais, por contemplarem os interesses de todos os envolvidos, por propiciarem que sejam eles os autores das decisões co-construídas e por oferecerem sigilo e celeridade nas negociações, não apenas viabilizam a continuidade de uma relação colaborativa e negocial entre os atores da divergência, como também proporcionam a maior exequibilidade dos acordos prevenindo futuras lides.

A mediação sob todos seus aspectos se traduz como um sistema facilitador, avaliativo e transformativo mostrando-se útil a temática ambiental. Independentemente da corrente a

\footnotetext{
${ }^{48}$ ALBERTO WARAT, L. $O$ oficio ... cit. p. 74
} 
qual se filie o importante é buscar uma melhor solução para que todos saiam ganhando, principalmente a natureza.

Verificamos que os maiores entraves contra a utilização da mediação socioambiental são a tradição antropocêntrica, a cultura jurídica adversarial e o caráter consumerista da atual sociedade, pautada em valores estritamente econômicos, por tal razão é que com uma visão meramente ideológica o movimento ambientalista e a mediação ora proposta podem sofrer algum tipo de pré-conceito e resistência por boa parte da população.

Contudo, o vetor transformativo da mediação, em especial nos casos de construção de consenso, mostra-se como verdadeiro instrumento de acesso à justiça, essa não só entendida como a efetivação de direito, mas como a observância daquilo que realmente seja justo, em especial uma justiça ambiental.

Pelo exposto, depreende-se que os fatores positivos superam os fatores supostamente considerados negativos para a aplicação da mediação nos conflitos socioambientais. Desta forma, e sendo os princípios e objetivos da mediação totalmente compatíveis com a proposta em análise, verificamos que a mediação se perfaz como um caminho adequado a busca pelos objetivos determinados pelo legislador na Constituição de 1988, ou seja, a formação de um país justo, igualitário, democrático e tendo como um de seus pilares a busca pela defesa, preservação e conservação de um meio ambiente ecologicamente equilibrado para as presentes e também para as gerações vindouras.

Assim é que podemos dizer que a mediação de conflitos na seara ambiental, além de ser um instrumento em prol da paz social, pode ser considerada uma forma de efetivação do direito fundamental ao meio ambiente ecologicamente equilibrado, destacando-se, ainda, por ser um meio de solução pacífica de conflitos inclusivo e transformador, respeitando os ditames democráticos tão buscados pelo povo brasileiro e auxiliando na construção de um Estado Democrático Ambiental de Direito no Brasil.

\section{REFERÊNCIAS}

“Constituição da República Federativa do Brasil de 05 de outubro de 1988”.

"Emenda n 1 ao Projeto de Lei da Câmara no 94 de 2002, de 21 de junho de 2006, referente ao Projeto de Lei $n^{\circ} 4827$ de 1998. Institucionaliza e disciplina a mediação, como método de prevenção e solução consensual de conflitos de Brasil”. 
“Lei n 13.105, de 16 de março de 2015, de Código de Processo Civil de Brasil". ALBERTO WARAT, L., O oficio do mediador, Habitus, Florianópolis, 2001. ALMEIDA, T., (2005). Mediação de conflitos: Um meio de prevenção e resolução de controvérsias em sintonia com a atualidade. Recuperado no día 33 de abril de 2015, de http://www.mediare.com.br/08artigos_13mediacaodeconflitos.html.

ARACELI HOYO SIERRA, I., "La idoneidad de los métodos alternativos de solución de conflictos", GONZALO QUIROGA, M. (dir.). BAZAGA FERNÁNDEZ, I.; GONZALO QUIROGA, M. y VENTAS SASTRE, R. (coord.), Métodos alternativos de solución de conflictos: perspectiva multidisciplinar, Universidad Rey Juan Carlos/Editorial Dykinson, Madrid, 2006.

BARUCH BUSH, R. y FOLGER, J., La Promesa de la Mediación: cómo afrontar el conflicto mediante la revalorización y el reconocimiento, Granica, Buenos Aires, Argentina, 1999.

BERNAL SAMPER, T., La mediación en escena, Editorial EOS, Madrid, 2012. BERNARDES DE SOUZA, J. R., A audiência pública e a mediação ambiental no processo de disputas públicas ambientais. Estudo de caso: EIA da Usina termoelétrica de Santa Branca -SP, 2003. Dissertação (Mestrado em Engenharia Civil), Campinas, Universidade Estadual de Campinas, 2003. $110 \mathrm{f}$.

BRAGA MARTINS, D. y DO CARMO BARROS, M., “A mediação como mecanismo de solução de conflitos ambientais e efetivação do princípio da participação social", Queiroz Caúla, B., Braga Martins, D., Menezes Albuquerque, N. y Moura do Carmo, V. (org.), Diálogo Ambiental, Constitucional e Internacional. v. 1, Premius, Fortaleza, 2013.

CALVO SOLER, R. (2012). Programa Compartim de gestió del coneixement. VII Jornada de Prevenció i Mediació Comunitària Escenaris del diàleg. Recuperado el 20 de octubre 2015, de $<\mathrm{http}$ //justicia.gencat.cat/web/.content/home/ambits/formacio_recerca_i_docum/biblio teca_i_publicacions/publicacions/materials_de_jornades/jornades_formacio_d_acces_lli ure/vii_jorn_prev_medi15112012/alcance_mediacion_raulcalvo.pdf $>$

CORSÓN PEREIRA, F. y GUTIÉRREZ HERNANZ, E., Mediación y teoría, Dykinson, Madrid, 2014. 
COSTA KOURY, A. B. y LEÃO SOUSA, D., "O Direito Ambiental sob a Perspectiva da Proteção Internacional à Pessoa Humana". Revista do Instituto Brasileiro de Direitos Humanos, v. 9, n. 9, pp. 11-28, 2009.

CUNHA, Í., "Insalubridade e Conflito ambiental: risco e cidadania". Revista de administração pública. Rio de Janeiro: Fundação Getúlio Vargas, v. 37. n. 02, pp. 427458, 2003.

DE ALBUQUERQUE ROCHA, J., Lei da arbitragem: uma avaliação crítica, Atlas, São Paulo, 2008.

FOLBERG, J. y TAYLOR, A. Mediación: Resolución de conflictos sin litigio. Limusa, México, D.F., 1996.

FRANCO CONFORTI, O. D. Incidencia de la Mediación de Conflictos en la Tutela Judicial Efectiva. Tesis (Doctorado en Derecho). Ciudad Real, España, Universidad de Castilla La Mancha, Instituto de Resolución de Conflictos, 2014. 341 p.

GONZÁLEZ-CAPITEL, C., Manual de mediación. 2. ed. Atelier, Barcelona, 2001. GRAZIOTTIN COSTA, T. N. y ZAMBAM, N. J. “A crise da jurisdição estatal: possibilidade de resolução de conflitos pela mediação e a perspectiva da moral e da autonomia da vontade na ótica Kantiana”, MIRANDA, J. y AMADO GOMES, C. (coord.), QUEIROZ CAÚLA, B. y MOURA DO CARMO, V. (org.), Diálogo ambiental, constitucional e internacional, Lisboa, Instituto de Ciências Jurídicopolíticas, 2015.

HERNÁNDEZ RAMOS, C. "Modelos aplicables en mediación intercultural”, BARATARIA: Revista Castellano-Manchega de Ciencias Sociales, núm. 17, 2014. HOllandA FERREIRA, A. B., Novo Dicionário Aurélio da Língua Portuguesa. 2. ed., Nova Fronteira, Rio de Janeiro, 1986.

HUFF THEODORO, S.; FIGUEIREDO CORDEIRO, P. M. y BEKE, Z., (2004) Gestão ambiental: uma prática para mediar conflitos ambientais. Anais do II encontro associação nacional de pós-graduação e pesquisa em ambiente e sociedade - ANPPAS. Indaiatuba: São Paulo, 2004. Recuperado en el día 10 de mayo de 2015, de $<$ http://www.anppas.org.br/encontro_anual/encontro2/GT/GT05/suzi_theodoro.pdf.> MAIA DE MORAIS SALES, L., Mediare: um guia prático para mediadores. $3^{\mathrm{a}}$ ed. GZ, Rio de Janeiro, 2010. 
MARCELO NATÓ, A. y RODRÍGUEZ QUEREJAZU, G., "Mediación comunitaria: practicar una ética de la paz”, GONZÁLEZ-CAPITEL, C. (coord.), Mediación x 7, Atelier, Barcelona, 2001.

MORÁN, G., "La mediación en EEUU: vías alternativas de negociación y resolución de conflictos: una nueva cultura socio-jurídica. La experiencia estadounidense”, SOUTO GALVÁN, E. (dir.), La mediación: un instrumento de conciliación, Dykinson, Madrid, 2010.

MORATO LEITE, J. R., Dano ambiental: do individual ao coletivo extrapatrimonial, Revista dos Tribunais, São Paulo, 2000.

MUNUERA GÓMEZ, P. "El modelo circular narrativo de Sara Cobb y sus técnicas”, PORTULARIA, v. VII, núm. 1-2, 2007.

OLIVEIRA NUNES, A. Poder judiciário e mediação de conflitos: a possibilidade da aplicação do sistema de múltiplas portas na prestação jurisdicional. Tese (Doutorado em Direito). Fortaleza, Brasil, Universidade de Fortaleza, 2014. 547 p.

ROSEMBUJ, F., "Nuevas formas de acción en la protección del ambiente: la negociación de la administración con el contaminador y la mediación de conflictos ambientales", GONZÁLEZ-CAPITEL, C. (coord.), Mediación x 7, Atelier, Barcelona, 2001.

SCHILLING-VACAFLOR, A. y FLEMMER, R. El derecho a la consulta previa: Normas jurídicas, prácticas y conflictos en América Latina. Deutsche Gesellschaft für Internationale Zusammenarbeit (GIZ) GmbH, Eschborn, Alemania, 2013.

SIMÕES BREDARIOL, C., (2004) O aprendizado da negociação em conflitos ambientais. Anais do II encontro associação nacional de pós-graduação e pesquisa em ambiente e sociedade - ANPPAS. Indaiatuba: São Paulo, 2004. Recuperado en el día 13 de mayo de 2015 , de $<\mathrm{http}$ :/Www.anppas.org.br/encontro_anual/encontro2/GT/GT17/gt17_celso_bredariol.p df. $>$

SINISTERRA RESTREPO, W. “Mediación Comunitaria”., Souto Galván, E. (dir.), La mediación: un instrumento de conciliación, Editorial Dykinson, Madrid, 2010.

SUSSKIND, L. y ZION, L., (2002) Can America's democracy be improved? Draft Working Paper of the Consensus Building Institute and the MIT-Harvard Public 
Disputes Program. 2002, Harvard. Recupera no día 13 de mayo de 2015, de $<$ http://www.lawrencesusskind.com/wp-content/uploads/2013/07/Improving-AmericanDemocracy-Negotiation-Susskind-Zion.pdf $>$ 